\title{
PEMANFAATAN APLIKASI EDMODO DALAM MENINGKATKAN PEMBELAJARAN BERBASIS DARING DI SMP 57 SURABAYA
}

\author{
Iwan Handoyo Putro' ${ }^{*}$, Petrus Santoso', Iman Subekti ${ }^{2}$ \\ ${ }_{1}^{1}$ Program Studi Teknik Elektro, Fakultas Teknologi Industri, Universitas Kristen Petra \\ 2Program Pendidikan Guru Sekolah Dasar, Fakultas Keguruan dan Imu Pendidikan, Universitas Kristen Petra \\ *Penulis korespondensi: iwanhp@petra.ac.id
}

\begin{abstract}
Abstrak: SMP Negeri 57 Surabaya merupakan sekolah dibawah naungan Pemerintah Kota Surabaya dan diresmikan oleh Walikota Surabaya Tri Rismaharini pada 12 Januari 2017. SMP 57 berlokasi di Kelurahan Siwalankerto, Kecamatan Wonocolo, Surabaya. Berdasarkan observasi yang telah dilakukan, didapatkan adanya permasalahan terkait TIK di sekolah ini yaitu laboratorium computer yang telah dimiliki belum dimanfaatakan secara maksimal. Terdapat 3 cluster permasalahan yang dapat didentifikasi (1) SDM belum cukup memadai untuk mengelola sistem TIK yang ada, (2) Aktivitas berbasis komputer belum terwujud, (3) belum adanya server sebagai fasilitas pendukung laboratorium komputer. Usulan solusi telah disusun untuk menjawab kebutuhan TIK di SMPN 57 Surabaya, yaitu: (1) mengadakan pelatihan aplikasi Edmodo bagi guru (2) membantu guru menyusun aktivitas pembelajaran berbasis Edmodo, serta (3) menyediakan server untuk mendukung aktivitas pembelajaran berbasis komputer di SMPN 57 Surabaya. Hasil angket menunjukkan bahwa 58\% peserta workshop sangat setuju bahwa pelatihan ini membantu mereka meningkatkan kemampuan pengelolaan aktivitas pembelajaran berbasis daring.
\end{abstract}

Kata kunci: Edmodo, pembelajaran daring, peningkatan kemampuan mangajar.

\begin{abstract}
SMP 57 Surabaya is a school under the auspices of the Surabaya City Government and was inaugurated by Surabaya Mayor Tri Rismaharini on 12 January 2017. SMP 57 is located in Siwalankerto Sub-District, Wonocolo District, Surabaya. Based on observations that have been made, it is found that there are problems related to ICT in this school, namely the computer laboratory that has been owned has not been maximally utilized. There are 3 problem clusters that can be identified (1) HR is not sufficient enough to manage the existing ICT system, (2) Computer-based activities have not yet materialized, (3) there is no server as a supporting facility for computer laboratories. Proposed solutions have been compiled to address the needs of ICT in SMPN 57 Surabaya, namely: (1) conducting Edmodo application training for teachers (2) helping teachers develop Edmodo-based learning activities, and (3) providing a server to support computer-based learning activities at SMPN 57 Surabaya. The results of the questionnaire showed that $58 \%$ of the workshop participants strongly agreed that this training helped them improve their ability to manage online-based learning activities.
\end{abstract}

Keywords: Edmodo, online learning, teaching skill improvement.

\section{PENDAHULUAN}

SMPN 57 (seperti terlihat dalam Gambar 1) berada di Jl. Siwalankerto Permai Blok G No.1, Kelurahan Siwalankerto Kecamatan Wonocolo, Kota Surabaya. SMPN 57 dibuka, sesuai dengan SK Pendiriannya yaitu didirikan tanggal 15 Juni 2016 dan diresmikan oleh Wali Kota Surabaya Tri Rismaharini pada Kamis, 12 Januari 2017 (Jatim, 2018).

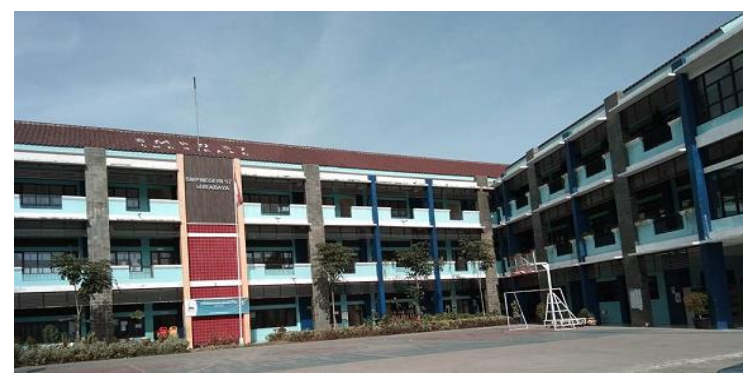

Gambar 1. Gedung SMP 57 Surabaya 
Jumlah murid yang telah diterima oleh sekolah ini adalah sebagai berikut:

1. Kelas 1 sebanyak 224 orang terbagi rombongan belajar;

2. Kelas 2 sebanyak 100 orang terbagi dalam 3 rombongan belajar; dan

3. Pada tahun pelajaran 2018/2019 kuota penerimaan murid sebanyak 228 orang.

Dengan demikianm total jumlah murid SMPN 57 pada tahun pelajaran 2018/2019 berjumlah 552 orang dengan jumlah guru sebanyak 13 orang serta dibantu 12 staf non akademik.

Tabel 1. Fasilitas SMPN 57 Siwalankerto

\begin{tabular}{llc}
\hline No Jenis sarana prasarana / fasilitas & Jumlah \\
\hline 1. & Jumlah ruang kelas & 26 ruangan \\
2. & Jumlah ruang guru & 1 \\
3. & Jumlah aula & 1 \\
4. & Jumlah ruang UKS & 1 \\
5. & Jumlah ruang OSIS & - \\
6. & Total luas lahan sekolah & $3.724 \mathrm{~m}^{2}$ \\
7. & Jumlah ruang laboratorium komputer & 2 ruangan \\
& (@luas $63 \mathrm{~m}^{2}$ ) & 55 \\
8. & Jumlah komputer (desktop) & $5,600 \mathrm{watt}$ \\
9. & Daya listrik & $5 \mathrm{hari} / \mathrm{minggu}$ \\
10. & Waktu penyelenggaraan pendidikan \\
\hline
\end{tabular}

Tabel 1 memperlihatkan kondisi dan jumlah fasilitas yang dimiliki oleh SMP 57 Surabaya. Dari data yang disajikan terlihat bahwa SMP 57 telah memiliki 2 Laboratorium komputer dan 55 (lima puluh lima) komputer desktop yang peruntukannya digunakan untuk (1) pembelajaran TIK, (2) mendukung pembelajaran berbasis daring, dan (3) mendukung ujian nasional berbasis komputer (UNBK).

\section{Analisis Situasi}

Secara khusus SMPN 57 meski sebuah SMP yang relatif baru namun telah mendapatkan bantuan komputer sebanyak 55 komputer dengan spesifikasi (Intel Core i5, RAM 8GB) dari Pemerintah Kota Surabaya. Sebanyak 55 perangkat komputer telah ditempatkan di 2 ruangan laboratorium komputer, 1 ruangan berada di lantai 1 sedangkan 1 laboratorium komputer lain ditempatkan di lantai 2.

Berdasarkan visitasi dan observasi lapangan yang telah dilakukan di SMP Negeri 57 Surabaya, disusun analisis situasi yang dikelompokkan dalam 3 (tiga) kluster permasalahan sebagai berikut: (1) Sumber Daya Manusia, (2) Aktivitas, dan (3) Sarana Prasarana.

1) Sumber Daya Manusia (SDM)

Guru dirasa kurang memiliki skill untuk menggunakan berbagai aplikasi pembelajaran berbasis komputer. SDM guru dirasa belum memadai untuk memaksimalkan fungsi labora- torium komputer untuk proses belajar mengajar, antara lain: latihan soal, ulangan harian secara otomatisasi menggunakan fasilitas TIK.

2) Aktivitas

Belum adanya aktivitas yang dibuat dengan memanfaatkan keberadaan Lab Komputer.

3) Sarana Prasarana

Belum tersedianya server di Laboratorium Komputer berakibat tidak maksimalnya pemanfaatan PC untuk mendukung kegiatan belajar dan mengajar.

Memperhatikan analisis situasi yang telah disusun, maka tim pengabdian masyarakat yang terdiri dari dosen dari Program Studi Teknik Elektro UK Petra bekerjsama dengan Program Studi Pendidikan Guru Sekolah Dasar UK Petra telah menyusun solusi permasalahan sebagai berikut:

1. Memberikan pelatihan bagi guru untuk menggunakan aplikasi Edmodo.

2. Membantu guru menyusun aktivitas belajar menggunakan Edmodo.

3. Menyediakan server yang akan dipakai dalam keperluan pembelajaran online berbasis komputer.

\section{METODE PELAKSANAAN}

\section{Edmodo}

Edmodo merupakan aplikasi berbasis daring yang menyediakan berbagai fasilitas untuk berkolaborasi bagi guru dan siswa (Kongchan, 2008). Edmodo menyediakan kemampuan untuk berbagi konten edukatif, menyusun sekaligus mendistribusikan kuis/tugas, serta mengelola komunikasi baik antar guru, siswa dan orang tua/wali murid.

Nilai lebih dari Edmodo adalah ketersediaan aplikasi di berbagai platform komputasi. Edmodo tersedia secara online melalui laman www.edmodo. com. Lebih lanjut aplikasi Edmodo juga tersedia di platform mobile baik untuk sistem operasi Android maupun IoS. Hal ini memudahkan adopsi dan pemanfaatan Edmodo bagi guru maupun siswa tanpa harus memperhatikan device apapun yang digunakan (Al-Said, 2015).

Lebih lanjut, dibandingkan dengan platform Learning Management System (LMS) seperti Moodle, Edmodo memiliki berbagai kelebihan, antara lain: user interface yang lebih sederhana, dukungan cloud dan social network, serta dukungan format file yang setara (Dhika et al., 2020)

Dari sisi siswa sebagai pengguna, Edmodo memiliki berbagai kelebihan. Pertama, tampilan apliaksi Edmodo mirip dengan Facebook (Holland and Muilenburg, 2011) sehingga memudahkan serta memotivasi siswa dalam menggunakan 
apliaksi ini dengan alasan familiaritas. Ketersediaan forum diskusi built-in didalam apliaksi Edmodo mendorong siswa untuk dapat berkolaborasi dengan siswa lain dalam mode luar kelas (Enriquez, 2014).

Penelitian mengenai pemanfaatan Edmodo bagi siswa SMP maupun SMA telah dilakukan sebelumnya dengan hasil secara umum: (1) motivasi siswa dalam belajar daring meningkat, (2) adanya peningkatan critical thinking selama dalam pembelajaran science, dan (3) peningkatan interaksi antar siswa selama pembelajaran daring menggunakan Edmodo (Wahyuni et al., 2020, Wahyuni et al., 2019, Wicaksana et al., 2020)

Meskipun pemanfaatan Edmodo telah dirasakan membantu guru dalam meningkatkan kualitas pembelajaran, dari hasil diskusi dengan pihak SMP 57 diperoleh informasi bahwa para guru belum pernah mendapatkan pengalaman untuk mengimplementasikan Edmodo dalam kegiatan belajar mengajar.

\section{Pembelajaran Daring}

Tuntutan aktivitas dan pekerjaan pada dunia modern ini menuntut setiap individu untuk memiliki literasi dalam memanfaatkan komputer untuk diaplikasikan pada dunia kerja. Hal ini tentu saja perlu diawali dengan pengenalan penggunaan komputer sejak dini kepada siswa-siswa supaya mereka tidak canggung dengan komputer.

Berdasarkan uraian singkat di atas maka kehadiran dunia pendidikan dituntut berdampingan dengan kehadiran dunia komputer. Kebutuhan komputer untuk dunia pendidikan yang modern adalah bersifat mutlak sebagai sarana teknologi informasi dan komunikasi (TIK) pendidikan. Betapa pentingnya kehadiran komputer pada lembaga-lembaga pendidikan sebagai sarana TIK di sekolah maka perhatian Pemerintah Kota Surabaya sangat besar untuk dapat memenuhi kebutuhan tiap sekolah akan komputer.

Keseriusan perhatian oleh Pemerintah Kota Surabaya pada tahun 2018 ini dibuktikan dengan menganggarkan dana sekitar Rp 52 miliar untuk pengadaan 5.000 komputer untuk sekolah SD dan SMP Negeri di Surabaya menjelang pelaksanaan UNBK SD dan SMP (Surya.co.id, 2018)

Beberapa langkah telah diambil untuk mendukung terlaksananya kegiatan pengabdian masyarakat di SMP 57 Surabaya. Kegiatan yang disusun berupa pelaksanaan workshop pelatihan pembelajaran berbasis aplikasi Edmodo bagi guru di SMP 57 Surabaya. Dalam pelatihan tersebut peserta tidak hanya dikenalkan dengan aplikasi Edmodo semata namun juga lebih jauh diperkenalkan dengan berbagai fiotur tingkat lanjut yang disediakan oleh Edmodo, antara lain: menyusun kuiz, kolborasi antar creator dan pemanfaatan
Edmodo sebagai sarana kolaborasi dengan siswa/ orang tua.

Berbagai langkah yang telah diimplementasikan dalam pelatihan pemanfaatan Edmodo tersebut, adalah:

1. Instruktur terlebih dahulu menyusun materi yang akan disampaikan. Pada tahap ini juga dilakukan koordinasi dengan mahasiswa yang akan membantu pelaksanaan pelatihan. Mahasiswa diminta untuk membantu peserta workshop dengan pertimbangan kemampuan peserta dalam mengadopsi materi berbeda-beda sesuai dengan kemampuan dan pengalaman sebelumnya dalam melaksanakan pembelajaran berbasis daring.

2. Dalam kegiatan ini guru di workshop hari pertama diperkenalkan dengan aplikasi Edmodo. Selanjutnya peserta diminta membuat kelas sesuai dengan mata pelajaran masing-masing yang diasuh. Kemudian peserta diminta membuat kuis sederhana dan memposting kepada siswa. Tugas ini diberikan sebagai pekerjaan rumah bagi para peserta.

3. Workshop hari kedua diawali dengan peserta diperkenalkan dengan berbagai mode assessment yang dimiliki oleh aplikasi Edmodo. Peserta workshop kemudian diminta menyusun berbagai kuis (antara lain: multiple choice, kuis benar salah, dan lain lain). Dia akhir pertemuan peserta diminta untuk memposting kuis yang telah disusun agar dapat diakses oleh siswa secara online.

4. Pada workshop hari terakhir, diawali dengan memberi kesempatan bagi peserta untuk menanyakan hal-hal yang masih belum dipahami. Hal ini dilakukan agar seluruh peserta dapat menyerap materi secara komprehensif. Pada kesempatan ini juga diedarkan angket untuk menilai keefektifan pelaksanaan kegiatan workshop serta feedback yang diharapkan dapat meningkatkan dan memperbaiki pelaksanaan workshop dimasa mendatang.

5. Untuk membantu pelaksanaan kegiatan belajar mengajar secara online dan melengkapi fasilitas Laboratorium Komputer yang telah ada, sebuah server telah didonasikan. Server ini dibutuhkan seiring dengan rencana pihak SMP 57 Surabaya untuk membangun 1 laboratorium Komputer sebagai upaya mendukung kegiatan PBM dengan semakin bertambahnya jumlah siswa.

\section{HASIL DAN PEMBAHASAN}

\section{Pelaksanaan Workshop}

Pelaksanaan workshop dilaksanakan di laboratorium Komputer SMP 57 Surabaya selama 3 hari, dimulai dari 29 Juli sampai dengan 31 Juli 
2019. Pelaksanaan workshop dilakukan pada sore hari mengingat aktivitas belajar mengajar masih dilakukan dari pagi sampai siang hari.

Tercatat 30 (tiga puluh peserta) mengikuti kegiatan workshop ini. Antusiasme terlihat besar karena peserta tidak hanya dari guru namun juga staf IT dan juga guru bantu yang terlibat dalam kegiatan belajar dan mengajar di SMP 57 Surabaya. Pelaksanaan Kegiatan workshop diperlihatkan pada Gambar 2, sedangkan hasil kegiatan pelatihan Edmodo berupa penyusunan materi pembelajaran daring diperlihatkan pada Gambar 3 dan Gambar 4. Adapun Gambar 5 dan Gambar 6 memperlihatkan salah satu contoh pemberian tugas Quiz secara daring berupa soal dengan tipe multiple choice.

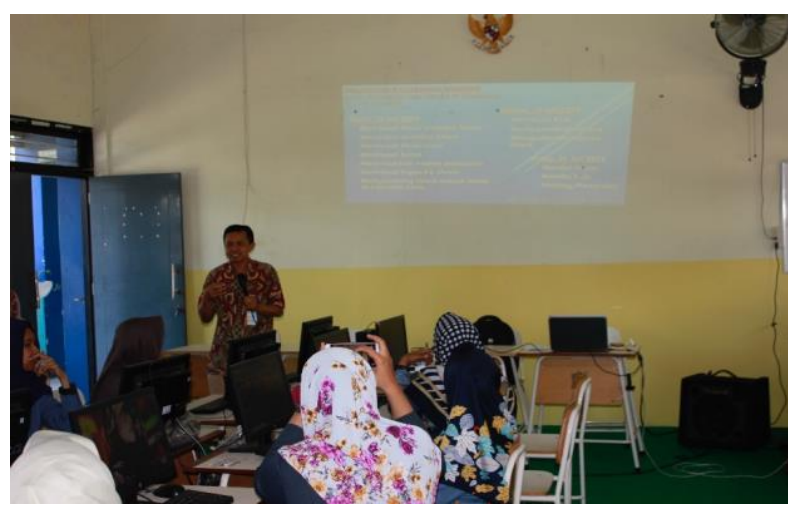

Gambar 2. Instruktur menyampaikan materi workshop

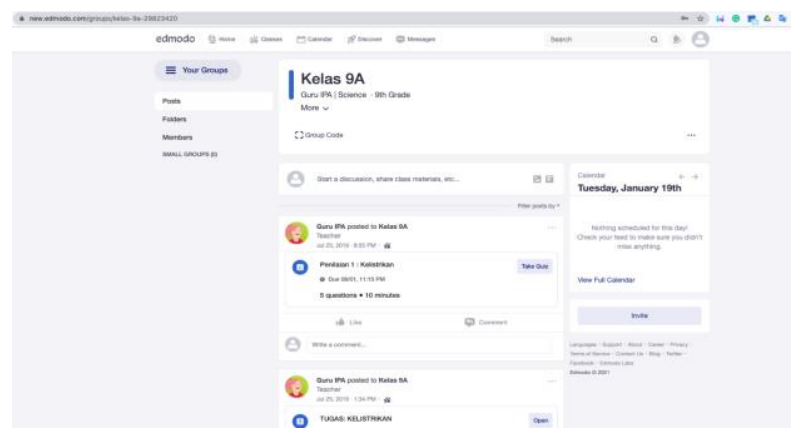

Gambar 3. Guru membuat kelas dengan materi pelajaran IPA

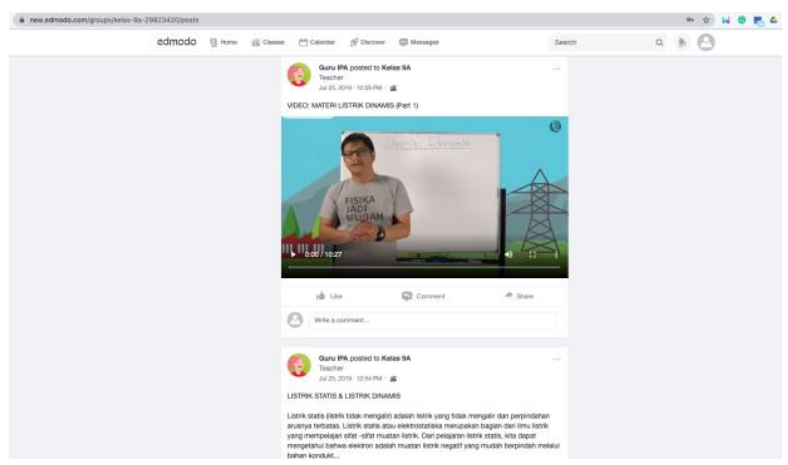

Gambar 4. Guru mengupload video sebagai salah satu materi pembelajaran

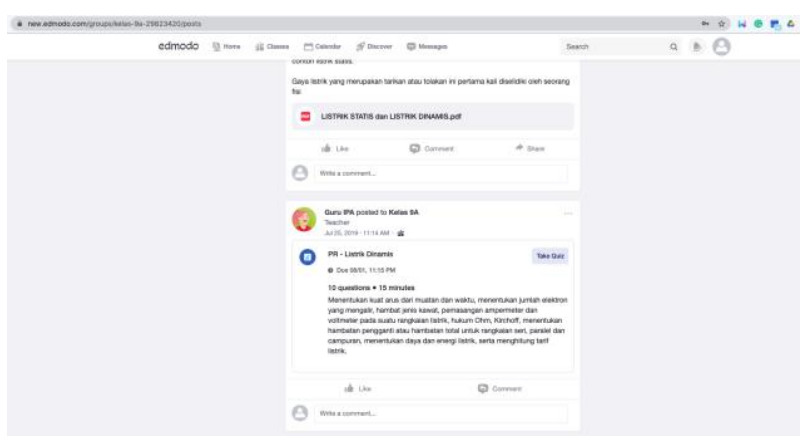

Gambar 5. Guru menyusun asesmen berupa Quiz

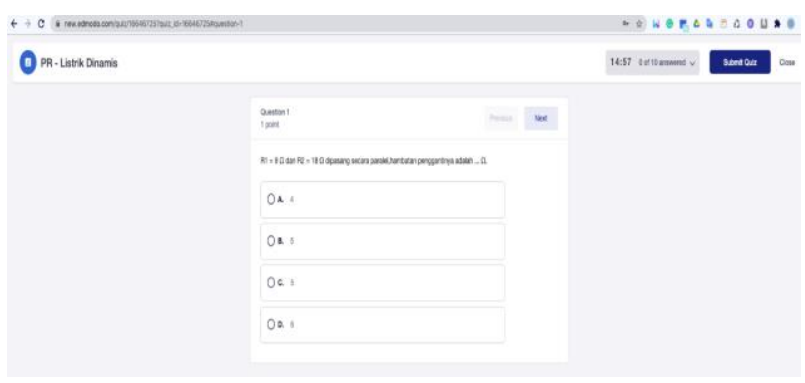

Gambar 6. Contoh soal Quiz dengan tipe multiple choice

\section{Evaluasi Pelaksanaan Workshop}

Evaluasi pelaksanaan workshop pelatihan aplikasi Edmodo diberikan dalam bentuk pengisian angket. Ada 3 hal yang ingin diketahui dari pelaksanaan angket yaitu terkait (1) assessment, (2) interaksi, dan (3) peningkatan PBM (pelaksanaan belajar dan mengajar). Pengisian angket bersifat voluntary, dari 30 peserta terdapat 19 peserta berkenan mengisi angket.

Untuk itu disusun sebuah angket dengan daftar pertanyaan sebagai berikut:

1) Kegiatan pelatihan dapat meningkatkan kemampuan saya dalam membuat penilaian secara online (assessment).

2) Melalui Edmodo dapat meningkatkan interaksi saya sebagai guru dengan siswa diluar pertemuan kelas (interaksi).

3) Kegiatan pelatihan dapat meningkatkan kemampuan saya dalam mengelola pembelajaran lebih bervariasi (peningkatan PBM).

Dari hasil Analisa angket didapat hasil responden sebagai berikut:

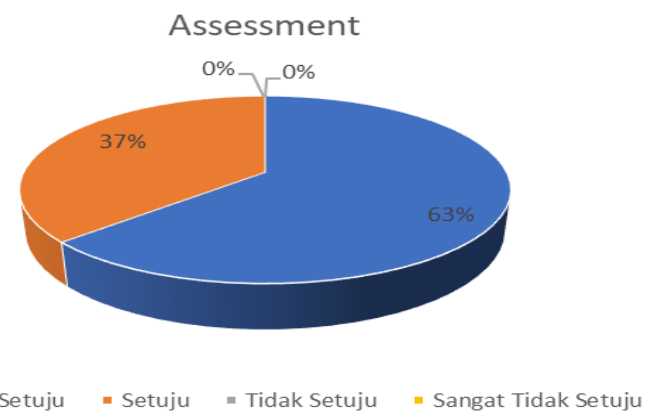

Gambar 7. Hasil angket terkait efektivitas pemanfaatan Edmodo dalam peningkatan proses assessment 
Gambar 7 memperlihatkan hasil angket kepada peserta workshop terkait dengan pertanyaan apakah pelatihan ini membantu guru dalam membuat penilaian secara online. Dari hasil angket diperoleh $63 \%$ peserta menyatakan sangat setuju dan sisanya $37 \%$ menyatakan setuju bahwa pelatihan aplikasi Edmodo ini dapat membantu peserta meningkatkan proses penilaian siswa secara online.

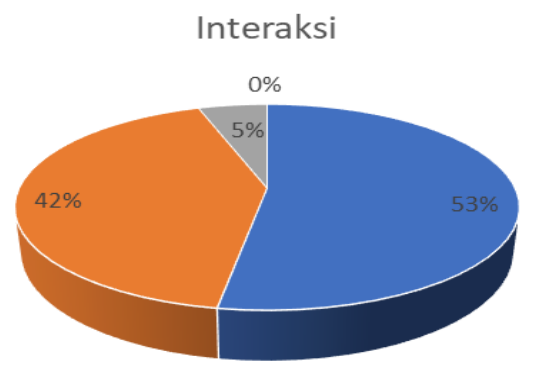

- Sangat Setuju = Setuju = Tidak Setuju $=$ Sangat Tidak Setuju

Gambar 8. Hasil angket terkait efektivitas pemanfaatan Edmodo dalam peningkatan proses assessment

Hasil yang sedikit berbeda terlihat pada hasil angket terkait apakah penggunaan Edmodo dapat membantu guru berinteraksi lebih baik dengan siswa di luar kelas. Dari hasil angket didapat 53\% peserta sangat setuju dan $42 \%$ menyatakan setuju. Namun terdapat $5 \%$ peserta yang menyatakan tidak setuju bahwa aplikasi Edmodo dapat meningkatkan interaksi guru dan siswa diluar kelas. Hal ini ini dapat dipahami karena pelaksanaan angket waktunya cukup dekat dengan pelaksanaan workshop sehingga peserta mungkin belum punya cukup waktu untuk merefleksikan hasil pelaksanaan workshop Edmodo.

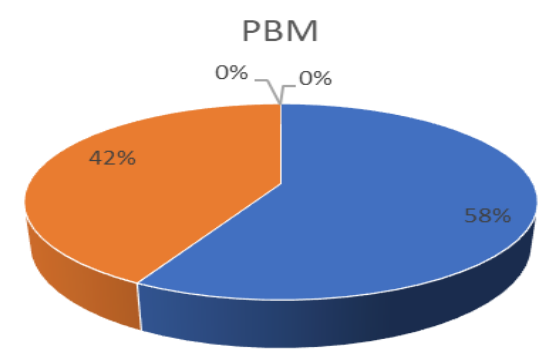

- Sangat Setuju - Setuju = Tidak Setuju = Sangat Tidak Setuju

Gambar 9. Hasil angket terkait efektivitas pemanfaatan Edmodo dalam peningkatan proses PBM

Pertanyaan angket terakhir berkaitan dengan apakah workshop ini dapat membantu peserta meningkatkan kemampuan dalam mengelola pembelajaran sehingga dapat lebih bervariasi. Hasil angket menunjukkan bahwa 58\% peserta sangat setuju dan $42 \%$ peserta menyatakan setuju bahwa pelatihan ini membantu mereka meningkatkan kemampuan dalam melakukan variasi pembelajaran. Hasil sharing salah satu peserta workshop menyatakan bahwa pemanfaatan Edmodo ini dapat membuka kemungkinan baru untuk melakukan variasi penyampaian materi kepada siswa. Terutama dalam mengantisipasi cara belajar baru diantara para siswa pada saat ini yang sangat dekat dengan dunia Internet maupun gawai.

\section{SIMPULAN}

Workshop pemanfaatan aplikasi Edmodo dalam mendukung pembelajaran daring di SMP 57 Surabaya telah berhasil dilaksanakan pada 29-31 Juli 2019 dengan lancar. Hasil pelatihan telah dirasakan oleh peserta dengan terlihat dari hasil angket yang diedarkan.

Di masa mendatang, kegiatan workshop ini perlu dilaksanakan dengan juga mengajak siswa sebagai pelaku pembelajaran. Dengan demikian, kedua belah pihak baik guru maupun siswa dapat memperoleh manfaat yang sebesar-besarnya dari aplikasi pendukung belajar yang digunakan.

\section{UCAPAN TERIMA KASIH}

Kegiatan pengabdian masyarakat di SMP 57 Surabaya ini didanai oleh Program Hibah Internal LPPM Universitas Kristen Petra Surabaya. Kegiatan ini juga didukung oleh mahasiswa Teknik Elektro dan mahasiswa PGSD Universitas Kristen Petra Surabaya. Ucapan terima kasih juga disampaikan kepada Kepala Sekolah dan Staf IT SMP 57 Surabaya yang telah mendukung kegiatan workshop.

\section{DAFTAR PUSTAKA}

Ali, Dini Salmiyah Fithrar. 2017. Marketing Public Relations - Diantara Penjualan dan Pencitraaan. Yogyakarta: DeePublish.

Bahri, A. Saeful. 2020. Manajemen Humas pada Lembaga Pendidikan. Bandung: Widina Bhakti Persada.

Hikmat, Mahi. M. 2018. Jurnalistik Literary Journalism. Jakarta: Kencana.

Kriyantono, Rachmat. 2014. Teori-teori Public Relations Perspektif Barat dan Lokal: Aplikasi Penelitian dan Praktik. Jakarta: Kencana.

Lesmana, Fanny. 2017. Feature Tulisan Jurnalistik yang Kreatif. Yogyakarta: Penerbit ANDI.

Morissan. 2014. Manajemen Public Relations. Jakarta: Kencana.

Rustan, Suriyanto. 2020. LayOut 2020 Buku 1. Jakarta: nulisbuku.com.

Sopian. 2016. Public Relations Writing. Konsep, teori, praktik. Jakarta: Grasindo.

Supadiyanto. 2020. Pengantar Jurnalisme Konvergentif Menjawab Tren Industri Media Digital. Yogyakarta: Pustaka Baru. 